\title{
CONSERVATION THROUGH EDUCATION
}

\author{
MARILYN H.S. LIGHT \\ Chair, Education Committee, Orchid Specialist Group \\ 174 Jolicoeur St. Hull, Québec, Canada J8Z 1C9. mlight@igs.net
}

The way to conservation is through education. People of all ages everywhere are learning how to make wise use of natural resources to ultimately benefit and sustain future generations but clear goals, objectives and analogies are needed to reinforce the message. Conservation education initiatives can be compared to production of a food crop. A crop plant must first be selected to suit the growing environment then the fields prepared for planting. After planting, the growing plants must be cared for. Only after a successful harvest can the profit be realized.

Clear goals and objectives are needed for conservation projects but before such activities begin, not only must we have developed the most appropriate plan for a particular project but also have recruited the human resources to do the work. We need individuals having strong conservation values acquired and reinforced in their communities. We need trained individuals possessing a wide range of skills, from nursery professionals and tourism operators to conservation officers and communicators, from project and financial managers to teachers and scientists. Planning is as important as doing, motivation and sharing through education and publication of information and ideas is equally fundamental. Seeley et al. (2003) observed that even good policies do not ensure success if the managers implementing programs are inadequately trained. Policy makers and conservation managers must have a broad range of skills and experience to develop and implement innovative and effective programs. Training programs should reinforce a sound understanding of project management, creative thinking and problem-solving.

According to Kassass (2002), the approach to biodiversity education at all levels should have five components including scale (local, national or international), overall strategy, goals, and project themes, and the evaluation of training program outcomes. Awareness programs are more likely to be effective if they are first well defined with measurable goals and outcomes, and subsequently designed to achieve the objectives. Many programs presently lack focus or even adequate evalu- ation tools to be of long term value.

Chapman and Kamala (2001) presented a strategy and methodology for establishing effective environmental education programs. They suggested that if biodiversity appreciation is considered as the unique domain of scientists then other local understanding and appreciation of what is a very complex issue risks being undervalued or ignored. We need to know what we have in terms of biodiversity if we are to adequately measure the success of resource management initiatives but lack of effective networking for biodiversity education and public awareness could further undermine and limit access to education and communication. If there is no formal process for evaluating education and communication programmes outside of the academic literature, local initiatives could fail without policy makers ever knowing why. Astill et al. (2002) observed in a multilevel analysis of the effects of parents, teachers and schools on student values in an Australian context that parental social position and the values held by parents and peer groups had much greater effects upon the students' values than the schools and their teachers. Young people especially should be encouraged to value orchids, their diversity and what that represents in terms of ecosystem health to their families and their communities. Mentorship programs and employment opportunities are equally valuable in transferring knowledge and resources to young people so they can develop their skills to make informed decisions about the profitable and sustainable management of orchids. Perhaps the most important role that the present generation can play is as mentors of youth. When we transfer knowledge and resources to youth, we not only contribute to their pursuit of excellence but we also provide an example for them to follow.

What can individuals do for conservation education? They can teach what they have learned. Knowledge gained through observation can be shared with neighbours and hobbyists, investigators and entrepreneurs, locally and internationally. Individuals can publish their observations and ideas in national and 
international publications or in peer-reviewed journals. They can advocate orchid conservation through their social and business affiliations by proposing the adoption and practice of sound conservation values and behaviours. They can debate topics and methodologies by participating in discussions with peers. Young people and students who are investigating orchid-related topics for school or related projects can be mentored to provide them with the best opportunity to reach their potential. Through contribution to bursary and scholarship funds, individuals can assist students pursuing higher learning in orchid-related areas.

Edward Warren Greenwood (1918-2002) was a Canadian orchidologist who made an important contribution to our understanding of Canadian and Mexican orchids (Reddoch \& Reddoch 2003, Light et al. 2003). When Ed Greenwood was a youth growing up in south western Ontario, Canada, a teacher proved pivotal to his career by supporting his acquisition of a photographic plate holder for a handmade pinhole camera. Further assistance to his education was provided in the form of a scholarship to attend Queen's University, Kingston, Ontario, where he studied engineering chemistry. While at university, Ed Greenwood began a lifelong quest to discover, photograph and otherwise document orchids. He retired to Oaxaca, Mexico in 1973 where he worked with mainly terrestrial taxa. The investment made by the teacher and the anonymous scholarship donors so many years before has been repaid many fold through the unselfish sharing of all Ed Greenwood knew and could teach to those who wanted to learn. He is acknowledged as being the most influential person in contemporary Mexican orchidology. Ed Greenwood ensured that a complete set of his field notes, herbarium specimens and photographic slide collection were deposited with AMO. A second set of notes and slides has been contributed to AMES.
When we transfer knowledge and resources to youth, we not only contribute to their pursuit of excellence but we also provide an example for them to follow.

There may be a critical need for orchid conservation education but we need to develop proven educational initiatives to be the vehicles by which such vital messages reach the desired audience. Appropriate messages need to reach everyone from the schoolchild to the tourist, from the farmer to the city dweller, from the policy maker to the conservation officer but we cannot overlook the fact that the message best understood and appreciated may be the one taught in the community by family members and peer groups. Orchids, their diversity and what they represent in terms of ecosystem health to families and their communities may be the most important message of all but the one representing the greatest challenge for delivery.

\section{Literature Cited}

Astill, B.R., N.T. Feather and J.P. Keeves. 2002. A multilevel analysis of the effects of parents, teachers and schools on student values. Social Psych.Educ. 5 (4): 345-363.

Chapman, D. and K. Sharma. 2001. Environmental attitudes and behavior of primary and secondary students in Asian cities: An overview strategy for implementing an eco-schools programme. The Environmentalist 21(4): 265-272

Kassass, M. 2002. Environmental education: Biodiversity. The Environmentalist 22 (4): 345-351.

Light, M.H.S., J.M. Reddoch, E. Hágsater and M. Soto. 2003. Edward W. Greenwood (1918-2002). Icones Orchidacearum, Fascicles V and VI. Orchids of Mexico, Part 2 and 3. pp. iii-vii.

Reddoch, J.M. and A.H. Reddoch. 2003. A tribute to Edward Warren Greenwood (1918-2002), Canadian orchidologist. Canad. Field-Nat. 116 (2): 326-330.

Seely, M.K., J. Zeidler, J.R. Henschel and P. Barnard. 2003. Creative problem solving in support of biodiversity conservation. J. Arid Environm. 54 (1): 155-164.

Marilyn H. S. Light was born in Montréal, Québec, Canada, receiving her post-secondary education in agriculture and microbiology at McGill University. She taught biology and botany in Barbados, West Indies and it was there, in 1970, that she began studying orchids. She joined the staff of the Professional Training Service, University of Ottawa, in 1981. Marilyn Light has developed and taught a range of orchid-related short courses on germination and identification. She conducts long term studies of Canadian terrestrial orchid populations of the genera Cypripedium, Epipactis, Platanthera and Spiranthes, investigating pollinator behaviour, pollen germinability, inter- and intra-clonal compatibility, and the impact of weather on individual and population behaviour. She has received the Anne Hanes Conservation Award from the Ottawa Field-Naturalists Club, and the highest award of the Ontario Horticultural Association, the Silver Medal Award, for her vision and achievements in horticulture. Marilyn Light is Chairman of the Canadian Orchid Congress Conservation Committee, and chairs the North American Region and the Education Committees of the Orchid Specialist Group. 